\title{
Manojlo Maravić
}

\section{(Ne)mogućnost primene tradicionalne filozofije, estetike, psihologije, pedagogije i sociologije igre na kritičku analizu video-igara}

UDC 316.774: [004.42:794

Apstrakt. Cilj ovog teksta je da se pruži kratak prikaz nekih od najznačajnijih filozofskih, estetičkih i kulturoloških teorija igre, a zatim analizira njihova istraživačka relevantnost u kontekstu razmišljanja o današnjim video-igrama. Igra kao filozofski i estetski problem ima veoma dugu tradiciju, i još su antički filozofi od Heraklita, Platona, Plotina i Aristotela u većoj ili manjoj meri razmišljali o igri. Ipak, ta antička tumačenja igre, osim u metaforičkom smislu, ne posmatraju igru kao estetski fenomen. Tek u 18. veku igra kod Kanta i Šilera zadobija važnu estetsku ulogu. Johan Hojzinga je izneo jednu od najrazrađenijih teorija igre, koja je značajna, jer prva napušta metafizička i psihološka situiranja igre, da bi je postavila kao fundamentalni kulturni obrazac. Povratak filozofskih interesovanja za pojam igre obeležili su filozofi evropske kontinentalne filozofske tradicije - Hans Georg Gadamer i Eugen Fink. Esencijalističke teorije, ontologije i apologije igre kao slobodne, utočišta od rada, dobrovoljne, humane, van sfere korisnog, bezbrižne, autonomnog vremena i prostora, kosmičke i igre sveta teško da bi mogle odgovarati problematici savremenih video-igara.

Ključne reči: igra, video-igre, filozofija, estetika, kultura

Cilj ovog teksta je da se pruži kratak prikaz nekih od najznačajnijih filozofskih, estetičkih i kulturoloških teorija igre, a zatim analizira njihova istraživačka relevantnost u kontekstu razmišljanja o današnjim video-igrama. Da bi se iznela kritička analiza tih teorija, markiraću, kod svake ponaosob, najvažnije i najuticajnije aspekte, koje one donose, $\mathrm{i}$ ispitati njihovo funkcionisanje u novoj igračkoj situaciji.

Igra kao filozofski i estetski problem ima veoma dugu tradiciju, i još su antički filozofi od Heraklita, Platona, Plotina i Aristotela u većoj ili manjoj meri razmišljali o igri. Heraklitova je čuvena zagonetna rečenica: „Vreme je dete koje se igra razmeštanjem 
kamičaka: kraljevstvo deteta“ (vidi kod Grlić, 1978: 45) podstakla brojne interpretacije, tumačenja i rasprave. Za Platona svet nije neka besciljna igra već umni poredak, ona se ne odnosi više na kosmičko kretanje, već na područje čulnosti. U svojim Zakonima on piše da je bit muzike naslađivanje i da je poput igre, jer ne donosi ,....niti kakvu štetu niti korist“. Platon je prvi postavio i pedagoško određenje igre, pa bi prema njemu decu trebalo podsticati da se igraju u cilju dobrog vaspitanja i učenja veština. Aristotel podržava ovaj Platonov stav o korisnosti igre za decu, ali i u VIII knjizi Politike dodaje još jedan važan princip igre koji će do današnjeg dana ostati paradigmatski i opšte mesto u definisanju igre. Ovaj princip se odnosi na igru odraslih, koju je potrebno posmatrati kao prekid od rada, jer u igri se „duša opušta i uživanje joj pruža odmor“.

Ipak, ta antička tumačenja igre, osim u metaforičkom smislu, ne posmatraju igru kao estetski fenomen. U tom smislu, korisno je sačekati 18. vek, kada igra zadobija važnu estetsku ulogu. U Kantovoj Kritici moći suđenja, na mestu gde on pravi razliku između umetnosti i zanatstva, kaže da je zanatstvo neugodna aktivnost dok je umetnost neka vrsta igre. Suprotstavljanje igre radu, koje se javlja još kod Aristotela, posle Kanta postaje neizbežno u postavljanju estetskih i antropoloških teza o igri. Igra je za njega oslobođena posledica i odgovornosti, ona je „svrhovitost bez svrhe“. Nakon Kanta, filozof koji je ponudio razrađenu estetsku kategoriju igre je Fridrih Šiler u svojim Pismima o estetskom odgoju čovečanstva. Kantove ideje o igri oslobođenoj od rada su u velikoj meri uticale na Šilerove postavke. Za njega je sloboda igre je dvostruka i nalazi se između nagona za materijom i nagona za formom. Funkcija nagona za igrom je da oba nagona, nagon za materijom koji isključuje slobodu i nagon za formom koji negira zavisnost, stavi pod kontrolu i tako omogući istinsku slobodu. Tako je samo u igri ostvarena harmonija između dvostruke prirode, duha i materije, iz koje se rađa čovek. Iz ovoga proizlazi njegova čuvena teza da je tek u igri čovek čovek, odnosno da se on ,igra samo kad je u pravom značenju reči čovek, i on je samo onda čovek kada se igra" (vidi kod Uzelac, 1999: 282). Na taj način, on igru postavlja na pijedestal ljudskosti, čovek je apsolutno slobodan samo u igri, ali treba napomenuti da ova sloboda nije moralne prirode, već je ona estetska sloboda. Šiler je začeo ideju o slobodi igre, odnosno o autonomiji igre, o zasebnosti i izmeštenosti igračkog prostora od realnosti u okviru koga se sloboda ostvaruje. Igra kod Šilera kao da zauzima neku vrstu ekskluziviteta u domenu estetskog, jer je protiv njenog prelivanja na druga područja, van sfere lepog. Za njega su umetnost i politika dva potpuno razdvojena područja, dok je umetnost mesto gde se ostvaruje celokupnost čoveka, politika je rezultat parcijalnosti i ne može nadići dva suprotstavljena nagona (za materijom i za formom), a time ne može ni biti u domenu igre.

Za razliku od Šilera i Kanta, Hegel nije cenio igru kao važan estetski pojam. Prema njegovom mišljenju, poistovećivanje igre i umetnosti donosi ovoj drugoj uživanje $u$ lakoj zabavi i prijatnosti. Ovakva primenjena i dekorativna umetnost ne bi zavređivala 
filozofsku refleksiju i ozbiljnu misaonu aktivnost. Kod Hegela je vidljivo negativno određenje igre, koje je često duboko ukorenjeno u zdravorazumskim rezonovanjima o igri, ona je, dakle, puka zabava.

Niče je smatrao da nema igre bez slobode, suprotstavlja je radu, a cilj igre je besciljno i u tome je bliska sa umetnošću jer i ona poput umetnosti zahteva sopstveno vreme i prostor van realnosti. Autonomija vremena je Ničeova ideja kojoj će on dati veliki značaj tokom svog filozofskog fokusiranja na igru, ali postaće i važna odrednica za buduća razmatranja ovog problema. Igra se odvija i postoji u svom sopstvenom vremenu slobodnom od realnog toka vremena. Vreme igre je tako "ograničeno", odnosno izuzeto od funkcionalnosti, svrhovitosti svakodnevnog, linearnog toka vremena. Svet igre je „večno vraćanje istog“, a u tom večnom vraćanju nalazi se i bit umetnikovog života. Igra tako postaje kosmička struktura (što će kasnije razraditi Fink), u okviru nje se ljudskost poistovećuje sa umetničkim.

Psihološka teorijaigreHerbertaSpensera izloženauknjizi ThePinciples of Psychology stavlja naglasak na relacije igre i estetike. Spenserov pojam igre je interesantan, jer ga poredi s pojmom lepog i kaže da kao što se lepo ne može dovesti u vezu sa procesom korisnosti, tako je i igra oslobođena funkcionalnosti i nalazi se iznad sfere korisnog (još jedna važna tačka u kasnijim definicijama igre). Spenserovo naturalističko razjašnjenje zasniva se na njegovoj interpretaciji ljudske evolucije. Čovek, zahvaljujući evolucionom razvoju i povećanim sposobnostima, ne troši svu energiju na pronalaženje hrane, već mu ostaje višak koji ispunjava u igri, nagon za igrom traži svoje pražnjenje. Isto tako se i estetska delatnost javlja samo onda kada je društvo dovoljno razvijeno da mu ostane višak energije za umetničko stvaranje. Za razliku od Spenserove problematične teorije igre, iz koje se veoma lako mogu izvući evropocentrične i rasističke konsekvence, Grosova zamisao igre je da ona ima konstitutivnu ulogu u pripremanju mladih za život. Prema njegovom stavu, a na tragu Platona, ona ima veoma važnu pedagošku svrhu jer razvija inteligenciju, vežba i privikava decu na kasnije dužnosti u svetu odraslih. Igra je tako najbolji metod učenja, a da bi to argumentovao povodi se, poput Spensera, naturalističkim objašnjenjima. On pravi poređenje igre životinja, koje kroz igru uče važne veštine za svoj opstanak, s dečjom igrom, koja priprema decu za buduće pozive, pa tako se „dečak instiktivno igra vojnika, a devojčica se igra sa lutkom“ (vidi kod Grlić, 1978: 61). Ovde je interesantno kako se politike identiteta, muškosti (spremanje za rat) i ženskosti (priprema majčinstva) i pozicije izvođenja društvenih uloga, naturalizuju i kako im se daje pedagoški značaj. Za definisanje igre interesantne su, iako od malog filozofskog i estetičkog značaja, ideje francuskog pesnika i esejiste Pola Valerija, gde igra postoji samo tamo gde se igrači žele igrati u cilju razonode i gde su slobodni da iz igre izađu kada to žele. Igra je tako dobrovoljna aktivnost.

Johan Hojzinga je u svojoj veoma uticajnoj knjizi Homo ludens izneo jednu od najrazrađenijih teorija igre, koja je značajna jer prva napušta metafizička i psihološka 
situiranja igre, da bi je postavila kao fundamentalni kulturni obrazac, i čak kao nešto iz čega je celokupna kultura nastala. On u prilog tezi da je igra starija od kulture uzima već poznati argument sa životinjama, ali za razliku od ranijih naturalističkih i fizioloških zaključaka on smatra da igra nadilazi te biološke funkcije. Hojzinga (1992) je ponudio jednu veoma iscrpnu definiciju igre:

„Sa formalnog stanovišta možemo, dakle, igru u zaključku nazvati slobodnim djelovanjem za koje osjećamo da 'nije tako zamišljeno' i da je izvan običnog života te da i usprkos tomu može igrača potpuno zaokupiti, uz koje nije vezan nikakav materijalni probitak a niti se njime stječe ikakva korist, koje protječe u vlastitom i određenom vremenu i prostoru, koje se odvija po određenim pravilima i oživotvoruje društvene veze, a ono sâmo rado se obavija tajnom ili se preoblačenjem izdvaja od običnog svijeta kao nešto zasebno" (str. 19).

Iako su nesumnjivo i prethodni mislioci primetili bezinteresnost igre $\mathrm{i}$ autonomnost vremena i prostora, Hojzinga je istakao "postojanje pravila" kao ključnog elementa igre, pa se tako ovaj princip može uzeti kao njegova odrednica u definisanju igre. "Ostvarivanje društvenih veza" nije bila zanimljiva tema za filozofe pri određenju ovog pojma, te je stoga ona takođe Hojzingin doprinos. On u svojoj knjizi opisuje razne oblike igre i njihova značenja u jeziku, pravu, ratu, znanju, filozofiji i kulturi, ali nije propustio ni priliku da spomene da je osobina igre „duboko usidrena u estetičkom“ (Huizinga, 1992: 10) U estetskom smislu najviše je posvetio pažnje odnosu igre i pesništva jer je poiesis funkcija igre. Pesništvo se nalazi sa druge strane ozbiljnog, ono izvire iz igre, svetih igara društvenih rituala prosidbe, takmičenja i svečanosti. Muzika je, kao i igra, sa one strane nužnosti, a sa njom deli iste elemente kao što su ritam i harmonija. Sa druge strane, veze između igre i likovnih umetnosti su labavije, dok se pesništvo, muzika i ples ostvaruju u izvođenju, u radnji koju Hojzinga naziva igrom, likovna umetnost je ograničene slobode, jer je upućena na mogućnosti materijala i to stvaranje proizvodi trajan rezultat bez ponavljanja.

Hojzingina teorija je pre svega kulturološke prirode, a to je prema rečima Danka Grlića (1978) upravo njeno ograničenje, jer ovaj nije uspeo da prosledi svoju misao „do nekih kozmoloških i ontoloških teza“ (str. 67). To se može posmatrati i obrnuto, odnosno da je Hojzinga, za razliku od njegovih filozofskih prethodnika, "prizemljio" igru u područje društva i kulture, gde joj je možda i mesto, i da je baš to njegov najveći uspeh.

Francuski teoretičar Rože Kajoa u knjizi Igre $i$ ljudi analizira fenomen igre sa sociološkog aspekta. U njoj je evidentan Hojzingin uticaj jer i Kajoa (1979) igru posmatra kao važan društveni obrazac, pa tako ,jedna civilizacija i unutar nje jedno doba, mogu biti karakterizirani svojim igrama.“ (str. 9). On se u najvećoj meri slaže sa prethodnom 
Hojzinginom definicijom i kaže da je igra: slobodna, izdvojena, neizvesna, neproduktivna, propisana i fiktivna. U pogledu samog definisanja igre Kajoa nije napravio veliku promenu u odnosu na prethodnike, ono što je kod njegove teoretizacije najznačajnije jeste iznošenje klasifikacije igara. On predlaže četiri kategorije: 1. agon - takmičenje (sportska takmičenja, šah, klikeri itd.); 2. alea - igre na sreću (kockanje, rulet, lutrije itd.); mimicry - prerušavanje (igranje uloga, scenske umetnosti) i 4. ilinks - zanos (vrteška, ples, hod po konopcu). Sve igre iz tih kategorija mogu se još raspodeliti između dva suprotna pola, sa jedne strane nalazi se paidia - neobavezna igra radi zabave (nestašluk, slobodna improvizacija, nekontrolisana fantazija, a sa druge je ludus - disciplinovana paidia (podvrgavanje proizvoljnim konvencijama, postavljanje prepreka).

Kajoa, kao i Hojzinga, pre njega, nije postavio ontološka pitanja o biti same igre, o njenom pojmu. Njegov pristup nije filozofski, već sociološki, on govori o raznim aspektima igara, a postavljena klasifikacija igara, kojoj je posvetio najviše pažnje, često će biti citirana od strane budućih istraživača ovog problema.

Povratak filozofskih interesovanja za pojam igre obeležila su dva filozofa evropske kontinentalne filozofske tradicije - Hans Georg Gadamer i Eugen Fink. Hans Georg Gadamer je u svojoj knjizi Istina i metoda, a u okviru razmišljanja vezanih za ontologiju umetničkog dela i njenu heremenautiku, istraživao pojam igre kao estetski fenomen. Kao ključnu tačku u razmatranjima tog problema uzima razdvajanje pojma igre od subjektivnog značenja, a upravo je to subjektivno značenje zauzimalo važnu mesto kod Kanta i Šilera. Gadamer (1978), u tom smislu kaže: „Kad u vezi s iskustvom umjetnosti govorimo o igri, onda pod igrom ne mislimo na ponašanje ili čak na duševno raspoloženje stvaraoca ili onoga koji uživa, a pogotovo ne na slobodu nekog subjektiviteta koji se aktivira u igri, već na sam način bitka umjetničkog djela" (str. 131). Na taj način igra ima svoju bit nezavisnu od svesti igrača. Da bi pokazao kako igra ne zavisi od subjektiviteta, već da je igra sama subjekt, Gadamer se okreće primerima iz njene upotrebe u jeziku. Prilikom korišćenja lekseme igra se uvek misli na neko kretanje "tamo-amo" koje nije orijentisano prema nekom cilju, pa se može govoriti o igri valova, igri komaraca, igri reči itd. Bitak igre je tako blizak bitku kretanja prirode, a smisao igre je, poput bitka prirode, ispunjenje i samopredstavljanje. Kako se do smisla igre može doći iz odnosa prema bitku umetničkog dela, pokazuje na primerima iz oblasti pesništva, drame i tragedije. Bitak umetničkog dela, poput igre, ne može se odvojiti od njegovog predstavljanja, od izvođenja i samoprikazivanja.

Gadamerov pojam igre i njegova relacija s bitkom umetničkog dela spada u red najpodrobnije razrađenih estetičkih određenja igre. Problem koji se javlja u vezi sa tom teorijom je ograničenje koje ona sama sebi nameće, odbacujući subjektivitet igrača. Njegova teorija je filozofski konzistentna i korisna za ontološka tumačenja igre, ali odbijajući da uvrsti subjekta igre u svoja razmišljanja, učinio ju je irelevantnom za sociokulturni pristup ovom problemu. 
Eugen Fink nastavlja nit nemačke filozofske tradicije i njenog interesovanja za pojam igre. Igru smatra legitimnim filozofskim problemom koji u potpunosti treba da uvaži bezbrižnost i naivnost igre (integralne elemente suštine igre). Fink igru, u svoj njenoj naivnosti, vidi kao dostojan predmet filozofije, a problemi koje istražuje vezani su za karakter nestvarnosti igre, relacije igre i drugih ljudskih životnih područja, ontološko i metafizičko preziranje igre (igra kao mimezis), mitski kult igre, kosmičku simboliku igre, igru bogova, igru sveta itd. Njegova tumačenja odnosa čoveka i sveta u igri imaju odlike fenomenološke metodologije, pa je tako čovek kroz igru otvoren prema svetu i ne postoji van njega, a njegov bitak sadrži u sebi tu otvorenost. Fink se suprotstavio duboko ukorenjenim stavovima da je igra suprotna od rada, da je pauza od rada, nazivajući ih "najpovršnijim" shvatanjima igre. Ipak, sledeća tvrdnja ga svrstava među one teoretičare koji se čvrsto drže dogmatizma o autonomiji igre, ona je autoreferencijalni pojam, odnosno: „Smisao igre nije nešto drugo od igre - igra nije sredstvo, oruđe, nije prilika da se izrazi neki smisao. Igranje je u samom sebi i kroz samu sebe smisleno" (vidi kod Božović, 2003: 29).

Esencijalističke teorije, ontologije i apologije igre kao slobodne, utočišta od rada, dobrovoljne, humane, van sfere korisnog, bezbrižne, autonomnog vremena i prostora, kosmičke i igre sveta teško da bi mogle odgovarati problematici savremenih videoigara. Naravno, može se reći da prilikom igranja video-igre imamo na raspolaganju slobodne izbore, želimo da se razonodimo i odmorimo u pukoj zabavi, pobegnemo u neku drugu realnost. To, međutim, ne bi bio kritički pristup tom problemu. Videoigre obezbeđuju nove prostore društvenosti čiji su virtuelni svetovi modusi postojanja savremene realnosti i društvenih, kulturnih i ekonomskih odnosa. Simulirani visokotehnološki prostor, u kojem se igra događa, ne može biti autonoman u vremenu kada simulacija postaje ključni kriterijum doživljaja realnosti rata, političkih odnosa i društvenih zajednica u okviru kojih cirkuliše kapital, gde se obrazuje, trenira za vojsku, reprezentuje Drugi i propagandno deluje, ali i uživa u uranjanju u virtuelni svet, povratnoj sprezi i teleprisutnosti. Video-igre su novi medij/sredstvo, nosilac poruke, ali i uranjajuća virtuelna sredina u kojoj se naše telo proteže. Prostorna izmeštenost video-igre od realnosti može se shvatiti samo u površnom smislu, kao odigravanje koje se dešava u izdvojenom virtuelnom prostoru generisanom na monitoru, ali prostor video-igre svakako nije odvojen od društvene realnosti, on nije apolitičan i autonoman, u okviru njega dejstvuju politike reprezentacije i identiteta, on se preliva u kulturni prostor, postaje predmet moralnih kritika, umetničkog i političkog delovanja. One su visokoestetizovan medij/sredina, na čijoj proizvodnji rade brojni umetnici: dizajneri, scenaristi, muzičari, glumci, režiseri i drugi. Prostor video-igre je i mesto stapanja subjekta i objekta, igrača i zastupnika koji tokom igranja postaje njegova telesna ekstenzija i sa kojim igrač ostvaruje kiborški odnos. 
Ostaje malo važnih filozofskih odrednica koje bi bile primenjive u današnjoj novoj igračkoj situaciji. Jedna od njih je Platonova ideja da igra može poslužiti kao pedagoška aktivnost. Ovaj koncept, koji su kasniji teoretičari i pedagozi rado prihvatali nalazi svoj politički prostor u produkciji obrazovnih video-igara, ovoga puta pod nazivom edutainment. $U$ današnjoj kulturi slike, gde se interpretacija slike vidi kao nova vrsta pismenosti, one su multisenzorni prostori: digitalne slike, zvuka, a ponegde i taktilnosti u kojima se odvijaju u većoj ili manjoj meri razrađeni narativi. Hojzingin uvid u značaj pravila koristan je kada se govori o bilo kojoj igri, a naročito o video-igrama jer su njena pravila tehnološki, a to znači, algoritamski određena. Njegova ideja o uspostavljanju (oživljavanju) društvenih veza je, takođe, nezaobilazna tema kada se govori o virtuelnim onlajn svetovima kao prostorima društvenosti. U Kajoinu kategorizaciju igara moguće je uklopiti neka žanrovska određenja video-igara i deliti ih na polove suprotstavljenog binarnog para - ludus i paidia. Međutim, ta vrsta formalne analize i strukturalističke dokse nije pogodna u istraživanju kontekstualnih i ideoloških značenja video-igara. Svet igre i sama igra jeste kontekst manifestovanja disperzivne političke moći i označiteljskih praksi u kojima se konstruišu koncepti patriotizma, neprijatelja, američkog vojnika, obrazovanja, umetnosti, zdravlja, ženskih, muških, crnačkih, belačkih, tehnoloških, zavisničkih i potrošačkih identiteta, čija algoritamska pravila mogu poslužiti kao metafora ideološke strukture, a interpelacija igrača kao interpelacija subjekta.

Da se igranje video-igre ne svodi na prekid od nužnosti ili rada govori činjenica da se danas mnoge igre koriste u obuci radnika („World of Warcraft"), profesionalnih vojnika (,America's Army”), ali i to da širom sveta, zahvaljujući internetu, mnogi igrači zarađuju igrajući. Iz navedenih primera proizlazi da igranje nije sasvim dobrovoljna aktivnost izvan sfere korisnosti, koja je sama po sebi smislena i bez ikakve materijalne dobiti. Postojanje sopstvenog vremena je isto, na prvi pogled, prihvatljiva teza jer svaka video-igra poseduje unutrašnje vreme sa kojim se može manipulisati, i u tom formalnom smislu ono je podložno analizi. Ono, u Ničeovom smislu, nije izuzeto od realnog toka vremena. Vreme u video-igri poseduje dualnost, pa pored unutrašnjeg zahvata i realno vreme koje igrač provodi za kompjuterom (Juul, 2004). Možda bi se njegova ideja o igri kao "večnom vraćanju istog" mogla vulgarizovati i porediti sa večnim vraćanjem sačuvane pozicije u video-igri, ali toj vrsti spekulacija u kritičkoj analizi nema mesta. Gadamerovo insistiranje na uklanjanju subjekta igrača iz analize pojma igre ne može pomoći ni istraživanju društvenog aspekta, ali ni u fenomenološkoj analizi video-igara, u smislu fenomenologije tela subjekta. Njegovo shvatanje kretanja "tamo-amo" kao suštine igre, koje se odvija i bez igrača, jako je široko postavljena kategorija da bi bila podesna za jednu kritiku video-igara, i navodi na mistifikacije pojma igre, gde je onda sve igra.

Kod većine pomenutih filozofskih teorija uspostavljene relacije između igre i estetskog, može poslužiti zalaganjima za umetnički legitimitet video-igara, ali te 
analogije su sasvim površne, jer ne posmatraju igru kao umetnost, već obrnuto umetnost kao igru. Ipak, duga tradicija ukazivanja na preplitanje ta dva područja, može da oslabi argumente onima koji smatraju da su video-igre samo igre i da kao takve nemaju veze s pojmom umetnosti.

Uzimajući sve to u obzir, smatram da su potrebni novi metodološki pristupi analizi video-igara jer su i one novi prostori društvenosti, one su medij (istovremeno sredstvo i sredina). Stoga esencijalistički filozofski pokušaji određenja pojma igre po sebi, samo odvlače pažnju od kritičkog odnosa prema video-igrama. Od svih navedenih, danas se najčešće citiraju, u semiološkim, ludološkim, naratološkim i generalno kulturološkim analizama, teoretičari Kajoa i Hojzinga jer su oni spustili ili uzdigli, zavisi iz kog ugla se posmatra, igru u područje društva i kulture, gde je njeno funkcionisanje i najubedljivije. To sve ne znači da je filozofija nepodesna za razmišljanje o problemu video-igara, već da je potrebno napraviti izbor i odabrati "alat" ne samo među onim teorijama koje eksplicitno govore o pojmu igre, već i među onim drugim, a tu, pre svega, mislim na Merlo Pontijevu fenomenologiju tela, a zatim i na novu fenomenologiju Masumija i Hansena. Diskurzivni okviri se kreću od naučnih semioloških, ludoloških, naratoloških, socioloških, psiholoških, estetičkih, fenomenoloških, pedagoških i kulturoloških teorija do militarističkih, moralističkih, umetničkih i industrijskih društvenih konteksta. Pored toga, zasluge Šilera, Šlegela, Ničea, Gadamera, Finka i drugih, uglavnom, nemačkih filozofa, kada je reč određenju pojma igra su nesporne. Oni su pokušali da o igri misle ozbiljno, da joj (u manjoj ili većoj meri) daju centralno mesto u svojim filozofskim istraživanjima i tako joj pruže legitimitet relevantnog naučnog problema. U tom smislu, njihova filozofija ima svoje mesto u izučavanju igre, bez obzira na predznak koji ona nosi sa sobom.

\section{Literatura:}

Božović, R. (2003). U traganju za dokolicom. Podgorica: Pobjeda.

Gadamer, H. G. (1978). Istina i metoda. Sarajevo: Veselin Masleša.

Grlić, D. (1978). Estetika III: smrt estetskog. Zagreb: Naprijed.

Huzinga, J. (1992). Homo ludens. Zagreb: Matica hrvatska.

Juul, J. (2004). Introduction to Game Time. In Wardrip-Fruin, N. \& Harrigan, P. (Eds.), First Person: New Media as Story, Performance and Game (pp. 131-133). London: The MIT Press, Cambridge, Massachusetts.

Kajoa, R. (1979). Igre i ljudi: maska i zanos. Beograd: Nolit. Uzelac, M. (1999). Estetika. Univerzitet u Novom Sadu. 


\section{(Im)possibility of applying traditional philosophy, aesthetics, psychology, pedagogy and sociology of play to critical analysis of video games}

Abstract: The aim of this paper is to give a short review of some of the most significant philosophical, aesthetic and cultural theories of play, and thereafter to analyse their research relevance in the context of reflection on today's video games. Play as a philosophical and aesthetical problem has had a long tradition and even the ancient philosophers ever since Heraclitus, Plato, Plotinus and Aristotle have more or less been thinking it. Nevertheless, those classical interpretations of play, except for their metaphorical sense, did not consider it as an aesthetic phenomenon. It was only in the $18^{\text {th }}$ century that play received an important aesthetic role in Kant's and Schiller's works. Johan Huizinga has presented one of the most elaborate theories of play, which is important as it abandons metaphysical and psychological positioning of play, to establish it as a fundamental cultural pattern. The return of philosophical interest for the concept of play has been marked by philosophers of continental European philosophical tradition - Hans-Georg Gadamer and Eugen Fink. Essentialist theories, ontology and apologies of play as free, a refuge from work, voluntary, humane, outside the sphere of utility, careless, with its autonomous time and space, cosmic and world play, could hardly correspond to the problem area of contemporary video games.

Key words: play, video game, philosophy, aesthetics, culture 